\title{
Assessment of the Health Risk Related to Air Pollution in Selected Polish Health Resorts
}

\author{
Izabela Sówka1*, Dominik Kobus², Krzysztof Skotak³ , Maciej Zathey4, \\ Beata Merenda ${ }^{5}$, Małgorzata Paciorek ${ }^{6}$
}

1 Wroclaw University of Science and Technology, Faculty of Environmental Engineering Unit of Engineering and Protection of Atmosphere, PI. Grunwaldzki 9, 50- 377 Wroclaw, Poland

2 inFAIR, ul. Puszczyka 10 m. 55, 02-785 Warsaw, Poland

3 Institute of Environmental Protection - National Research Institute, Integrated Environmental Monitoring Department, ul. Krucza 5/11d, 00-548 Warsaw, Poland

4 Wroclaw University of Science and Technology, Faculty of Architecture, Department of spatial planning and settlements processes, 50-317 Wroclaw, B. Prusa 53/55, Poland; Institute for Territorial Development, 50-527 Wroclaw, J. Wl. Dawida 1a, Poland

${ }^{5}$ Chief Inspectorate of Environmental Protection, Voivodship Inspectorate for Environmental Protection in Wroclaw, Department of Inspection, ul. Józefa Chełmońskego 14, 51-630 Wrocław, Poland

6 Biuro Studiów i Pomiarów Proekologicznych EKOMETRIA Sp. z o.o., ul. Elbląska 66, 80-761 Gdańsk, Poland

* Corresponding author's e-mail: izabela.sowka@pwr.edu.pl

\begin{abstract}
The article discusses the tools used for air quality management in the health resorts in Poland including legal instruments, documents and activities at the regional and local level with an example of formal and legal activities, such as the so-called anti-smog resolution to limit the emission of air pollutants from the municipal and housing sectors and thus minimize the risk related to air pollution. The issue of pollution emission resulting from the spatial conditions, including spatial planning, was also indicated. The analysis of the results pertaining to the $\mathrm{PM}_{10}$ measurements from 2017-2018 available for the resorts in Lower Silesia with reference to selected resorts in other regions of Poland and the health risk assessment according to the concentration-response functions for the PM-based on long- and short-term relative risk estimates derived from epidemiological studies were conducted. The exposure assessment was based on the available mathematical modelling results for the $\mathrm{PM}_{10}$ and $\mathrm{PM}_{2.5}$ concentration distributions, which was performed using the CALPUFF model for 2017. In the case of average risk indicators, the obtained values indicated that the values (for all the stays and areas of all zones (total A, B and C) peaked for the Cieplice Śląskie-Zdrój health resort (over 1.1\% per annum) and were lowest for Czerniawa and Świeradów-Zdrój (about 0.7\%). The highest relative risk indicators in 2017 were observed for cardiovascular diseases for the first two stays in January / February (for the Cieplice Śląskie-Zdrój health resort - over 5\%) and for both December stays (over 2.5\%). In other health resorts, the risk indicators were significantly lower. The lowest health risk indicators were observed in July, regardless of the location of the health resort and the analysed health effect (rarely exceeding $0.3 \%$ ). The scale of risk in this case was much higher compared to the short-term risk.
\end{abstract}

Keywords: air quality, health resorts, mathematical modelling, health risk assessment

\section{INTRODUCTION}

Air pollution affects health substantially [WHO, 2006] and plays a key role among the environmental threats [Lim SS et al., 2013]. Prolific epidemiological research has proven the correlation between the air pollution and negative health effects in the general population [Samet, Krewski, 2007]. Sensitive groups, including the elderly, children, pregnant women and the chronically ill are generally more threatened and thus prone to more serious 
health effects resulting from the exposition to air pollution than the general population [WHO, 2006]. Studies prove that the exposed have higher risk of suffering from lower respiratory tract diseases, chronic obstructive airway disease, stroke, coronary artery disease and lung cancer [WHO, 2016]. Therefore, particularly in health resort treatment, the role of which is providing complex healthcare as well as reducing the incidence and premature mortality from cardiovascular diseases, chronic respiratory diseases and detrimental health effects caused by harmful factors in the working and habitual environment [Team appointed by the Regulation of the Polish Minister of Health, 2017]. The adequate quality of environment, including the climatic conditions and atmospheric air quality, constitutes an essential aspect. Therefore, improving the air quality, especially in health resorts, should play a key role in the countrywide strategy of reducing the atmospheric air pollution.

The aim of this work was characterising selected elements of the air quality management system in Polish health resorts extended with the analyses of air quality performed on the basis of the measurements of the $\mathrm{PM}_{10}$ particulate matter concentration within the State Environment Monitoring and the results of modelling used in the end for health risk assessment.

\section{CHARACTERISTIC OF SELECTED ELEMENTS OF THE AIR QUALITY MANAGEMENT SYSTEM IN HEALTH RESORT TOWNS}

\section{Juridical and formal solutions}

The towns with health resort status must the fulfil criteria determined by Polish legislation in the resort therapeutics, health resorts, resort protection areas and resort boroughs act [Polish Journal of Laws, 2005 No. 167 item 1399 with later changes]. They must demonstrate, among other things, the remedial qualities of the climate favouring the preservation of health, healing or easing the effects or symptoms of illnesses.

The undertakings aiming at air quality improvement can be divided into the following main groups:
- creating laws constituting the formal and judicial basis for air protection

- physically eliminating the air pollution sources

- preparing the financial instruments aiding the process of eliminating air pollution sources

- education and actions aiming at raising the awareness of the broadly defined air protection

Granting or maintaining the health resort status must be preceded by preparing a health resort study, i.e. a report containing the characterisation of the resort, available natural therapeutic resources and the pro-healthful features of the climate. The commune, in which the resort or resort protection area is situated, is obligated to prepare and present the study at least every ten years. However, a decade seems too long considering the dynamic city structure transformation processes and the size of investments which may negatively affect the environment, including the state of atmospheric air in the resort. The health resort study must confirm that the town fulfils the criteria, on the basis of which the minister competent for health makes the decision of granting or maintaining the health resort status.

Since 2014, in the Lower Silesian Voivodeship, an air protection program (APP) has been in effect [Official Journal of the Lower Silesia, February 25, 2014, item 985, Official Journal of the Lower Silesian Voivodeship, November 2 2017, item 4475]. It formulates the recommendations, involving reparative actions aiming at reducing the pollution of air with $\mathrm{PM}_{10}, \mathrm{PM}_{2.5}, \mathrm{~B}(\mathrm{a}) \mathrm{P}$ and $\mathrm{CO}$, addressed at agglomerations and the so-called Lower Silesian zone, which includes the Lower Silesian health resorts and lies outside the larger cities. Despite the enaction of the program, the magnitude of pollution emission is constant. The lack of shaping responsible social attitudes and financial aid, as well as the lack of the public sector support for implementing the solutions recommended by APP is responsible for this fact. Every Lower Silesian resort borough possesses an enacted Low-emission Economy Plan (LEP), a strategic document, important for reducing the emission of pollution. The actions contained therein are to, inter alia, improve the air quality where limit levels have been exceeded and where air protection programs are executed [Pietrzyk-Sokulska, et al., 2016]. In order to improve the air quality in the framework of programs reducing low emission (PRLE), the resort boroughs have also taken the action encompassing the elimination of coal-fired heat sources. 
The bans and limitations on the exploitation of installations in which fuels are burnt have been in effect since July 1st 2018 in the Lower Silesian Voivodeship. It has been so due to three acts, the so called anti-smog acts, passed by the Lower Silesia Voivodeship Regional Council on the 30th of July 2017. One of these three acts concerns the areas of resorts, where it introduces the limitations and bans on the exploitation of installations in which fuels are burnt [Official Journal of the Dolnośląskie Voivodship, December 8. 2017. item 5154].

On the basis of the analysis pertaining to the ecological effect of introducing bans and limitations on the exploitation of solid fuel burning installations, the act passed by the regional council introduces two categories of bans to the Lower Silesian health resorts [https://irt.wroc. pl]. In order to prevent the negative effects on health and environment, a ban on the usage of brown coal and solid fuels produced with this coal, coal sludge, coal flotation concentrates and mixtures made with these, culm and wood the humidity of which in working state exceeds $20 \%$, was introduced to the following resorts: Jelenia Góra-Cieplice-Zdrój, Duszniki-Zdrój, Jedlina-Zdrój, Kudowa-Zdrój, Lądek-Zdrój, Polanica-Zdrój, Szczawno-Zdrój. Combustion of good quality coal for heating purposes will be possible until July 1, 2028; afterwards, in accordance with the act, a ban on the usage of solid-fuel-powered installations will be enacted in these towns. Slightly more liberal legislation was prepared for the Czerniawa-Zdrój, Świeradów-Zdrój, Długopole-Zdrój and Przerzeczyn- Zdrój resorts. In these four resorts, burning solid fuels, including high-energy coal, will be allowed on the condition that the installations used will fulfil the minimal season energy effectiveness levels and pollution emission norms for seasonal heating of rooms determined in the EU Ecodesign Directive.

A crucial difference between the air protection program and the anti-smog act consists in defining the final recipient of the document. The subject responsible for the realisation of APP, consisting of the recommended reparative actions is the borough self-government, whereas the anti-smog act constitutes a legal framework and an obligation for the inhabitants, who are the users of fuel-burning installations. Therefore, the anti-smog act is a legal instrument of much greater influence.

\section{Methods of air quality assessment}

One of the tools aiding the processes of air quality management in Polish resorts is conducting the air quality assessments in accordance with the current legal regulations, such as the 27 April 2001 act - Polish Environmental Protection Act [Journal of Laws, 2018, item 799, as amended], or Regulations of the Polish Minister of the Environment from 8 June, 2018 regarding the assessment of levels of substances in the air [Journal of Laws, 2018, item 1119] and from August 24, 2012 on the concentrations of some substances in the air [Journal of Laws, 2012, item 1031]. These regulations are adapted and compatible with those determined in the EU documents, especially in directives 2008/50/WE [Official Journal of the EU L. 152 of 11.06.2008] as well as 2004/107/WE [Official Journal EU L 23 of 26.01.2005]. The analysis of air quality was conducted as a part of State Environment Monitoring (SEM) [Chief Inspector for Environmental Protection. 2015], which is overseen by the Chief Inspectorate for Environment Protection (CIEP). SEM is the source of information about the environment, stemming from the measurements and evaluations of its state, as well as the analysis on the impact of different factors, including human activity. In the case of air quality, the evaluation is conducted via a network of measurements of the selected air pollutants concentrations, complemented with the techniques of mathematical modelling and objective estimation. The monitoring research is conducted in a cyclical manner, using uniform methods of gathering, storing and processing data. An important matter concerning NEM is the use of referential measurement methods or equivalent ones with proven accordance to referential methods, as well as designing and maintaining a system of measurements quality control and assurance. The results of measurements and forecasts are also used for the on-going air quality management on a local level, for example by implementing and starting short-term action during the episodes of high pollution concentrations, directly threatening the health of inhabitants. In such situations, an important feature of monitoring and modelling is informing and warning the society, particularly important for the sensitive groups (e.g. children, the elderly or the ill).

The monitoring system is mainly based on the networks of measurement stations deployed in critical points of respective voivodeships, mainly 
in cities. At the moment, in the health resorts there are 24 measurement stations (around 150 sampling points) altogether, of which 4 stations (around 20 sampling points) function in Lower Silesian resorts: Czerniawa-Zdrój, Duszniki-Zdrój, Cieplice Śląskie-Zdrój and Szczawno-Zdrój. The measurement stations usually have a fixed localisation, where research is conducted in multiannual periods, which allows, i.a. for assessing the variability of pollution levels in time. In the Polish resorts, there are also mobile stations, conducting measurements in a given place for a period of e.g. a year, with the goal of identifying the present air quality problem. The stations are situated in different resort protection zones: A, B and C, and have a diversified measurement program.

For the purposes of carrying out the annual air quality assessments as well as informing the society about the current and forecast air quality, mathematical modelling enabling spatial analysis of pollutant concentration distribution is used complementarily. It is used particularly in order to determine the areas with exceeded normative levels, which is important as the measurement points are placed relatively sparsely. The modelling takes in account the magnitude of pollution emission in a given area, meteorological conditions, topographical conditions and other factors. Modelling plays an important role, providing data for the areas where measurements are not taken. Moreover, many units conduct modelling for APPs or to provide a local pollutant concentration forecast. Among other models, the CALPUFF model is used. It was also used for modelling, the results of which were analysed in this publication.

\section{RESEARCH METHODOLOGY}

\section{Measured data used in analyses}

The air quality analysis in health resorts was conducted with use of the results pertaining to the PM10 particulate matter concentrations in the context of keeping the standards established for health protection, on the basis of the results from the measurement stations included in the SEM network (table 2). However, the stations situated in boroughs, where resorts are situated, but located outside the boundaries of resorts, were not taken into account. The source of the data used was the measurement data bank available on the CIEP Air Quality Portal [http://powietrze.gios.gov.pl/pjp/archives]. A detailed analysis was carried out for years 2017 and 2018, for the available results of concentration measurement conducted in Lower Silesian resorts. The data presented was cross-referenced with the situation in exemplary resorts of different character, situated in different regions of the country: lowlands and the seaside, as well as the situation in Poland overall. In a few cases, a variability analysis of select statistical parameters has been conducted, corresponding to air quality standards of the last few years. It was possible for the stations, for which the multiannual measurement series with the same localisation conditions, are available.

The variability of 24-hour concentrations was presented with use of the $\operatorname{Smax} 36$ parameter, which is the 36 th value in a non-increasing series of daily concentration values from a given calendar year. It is a parameter connected to the definition of limit $\mathrm{PM}_{10}$ value. If the value of Smax36 exceeds $50 \mu \mathrm{g} / \mathrm{m}^{3}$, one can deduce that more that the allowed 35 cases of exceeding the permissible level of D24 $=50 \mu \mathrm{g} / \mathrm{m}^{3}$ have occurred in the given year or that the permissible 24-hour concentration for $\mathrm{PM}_{10}$ was exceeded in the given localisation.

Apart from an analysis of the values of statistical parameters calculated with the measurement series results, an assessment on the seasonal variability of the concentrations of $\mathrm{PM}_{10}$ particulate matter was also carried out. In the conducted analyses and comparisons of concentration variability, the WSa and WSmax36 indicators were used to represent the variability of multiannual particulate matter concentrations in the reports published by the CIEP [Iwanek J., et al. CIEP. 2018]. The indicators for Poland, for each year separately, were calculated in two stages. In the first stage the average value of the parameter in question was established on the grounds of the results of the $\mathrm{PM}_{10}$ concentration measurements from measurement points in urban and suburban backgrounds, for each voivodeship. At the second stage, the countrywide indicator was calculated as a weighted average of the voivodeship values, where the weights were the numbers of inhabitants of a respective voivodeship. The value of the Wsa indicator, based on mean annual concentrations from 2017, equals $31.7 \mu \mathrm{g} / \mathrm{m}^{3}$, whereas $W \operatorname{Smax} 36$, based on the 36th maximum of 24-hour concentration measurement series form 2017 is $58.6 \mu \mathrm{g} / \mathrm{m}^{3}$. 
In table 1, the measurement stations of urban background from the Lower Silesian Voivodeship resorts, from which the results were included in analyses, were juxtaposed. Furthermore, the $\mathrm{PM}_{10}$ particulate matter concentration results from two urban background stations situated in the seaside resort Sopot (Pomeranian Voivodeship) and in the lowland resort Busko-Zdrój (Świętokrzyskie Voivodeship) were used for comparisons.

\section{Mathematical modelling}

The results of the presented modelling analyses were obtained through use of a system (drawing 1) based on the II generation puff model (CALPUFF), fed with data from the WRF (Weather Research And Forecasting Model) meteorological model and with a designed emission model, utilising a detailed inventory of information about pollution sources in the Lower Silesian Voivodeship [VIEP Wrocław, 2014]. In the air quality calculations, the inflow of pollution from outside the voivodeship in the form of temporally and spatially changeable boundary conditions derived from calculations with a model of transport and chemical transformations (CTM) was also included.

The dispersion model utilised considers the temporally and spatially variable meteorological data, allowing for a more accurate reproduction of the processes occurring in the atmosphere. The variability of the information throughout space also determines a better consideration of the terrain characteristics (landform and usage) in the context of air quality. It is particularly important in the case of the Lower Silesian Voivodeship, which is characterised by high complexity of terrain landform. That is why two resolutions of meteorological grids were used in the calculations $5 \mathrm{~km}$ for lowland terrain and $1 \mathrm{~km}$ for mountainous terrain. The pollution concentrations were calculated in discrete receptors based on different grid resolutions, namely $0.5 \mathrm{~km}$ in Legnica,
Wałbrzych and Wrocław, $0.25 \mathrm{~km}$ in small cities and health resort areas, and $1 \mathrm{~km}$ in the remaining areas. The modelling calculation results obtained were validated by comparison with the available NEM measurements. The last assessment, the results of which are presented in this work, performed with the above-mentioned methodology, took place in 2017 [VIEP Wrocław, 2018].

\section{Health risk assessment}

The health risk assessment connected to air pollution was conducted for 11 resorts in Lower Silesia (Table 2). In four of them, DhugopoleZdrój, Cieplice Śląskie-Zdrój, Lądek-Zdrój i Przerzeczyn-Zdrój, the diseases dependent on the air quality, including: chronic diseseses of lower (1) and upper (2) respiratory tract and cardiovascular system (3) are not treated. Additionally, the Kudowa-Zdrój resort is not concerned with the pulmological diseases in its operation. However, this does not mean that the risk connected to air quality is negligible in these resorts, for nearly the entire borough population lives in the delineated $\mathrm{A}, \mathrm{B}$ and $\mathrm{C}$ resort zones. Exceptions are Cieplice Śląskie-Zdrój and Długopole-Zdrój, which are inhabited by only a small part (11.3\%) of the resort borough population.

In the analyses, the sample-response function using the relative risk (RR) indicators determined on the basis of epidemiological research was used [WHO, 2013 a]. These indicators determine the probability of the occurrence of adverse health effect in a given population as a result of exposure to large pollution with time of exposure and concentration considered, relative to the population of lower risk. Because RR is usually expressed as the proportional increase of the assessed health score connected to a given increase in pollution concentration in $\mu \mathrm{g} / \mathrm{m}^{3}$ or ppb [Katsouyanni, 2003], the rule of attribute proportion was used in risk assessment. In the evaluation of resorts the $\mathrm{RR}$ indicators were used for hospitalization risk

Table 1. Measurement stations included in the conducted analyses.

\begin{tabular}{|l|l|l|}
\hline Health resort & Station code & Adress \\
\hline Cieplice Śląskie-Zdrój & DsJelGorSoko & Jelenia Góra, ul. Sokoliki 6 \\
\hline Kudowa-Zdrój & DsKudowaMOB & Kudowa-Zdrój, ul. Tadeusza Kościuszki 16 \\
\hline Lądek-Zdrój & DsLadekMOB & Lądek-Zdrój, ul. Św. Królowej Jadwigi \\
\hline Szczawno-Zdrój & DsSzczaKolej & Szczawno-Zdrój, ul. Kolejowa 14 \\
\hline Sopot & PmSopBitPI06 & Sopot, ul. Bitwy pod Płowcami \\
\hline Busko-Zdrój & SkBuskRokosz & Busko-Zdrój, ul. Rokosza 1 \\
\hline
\end{tabular}




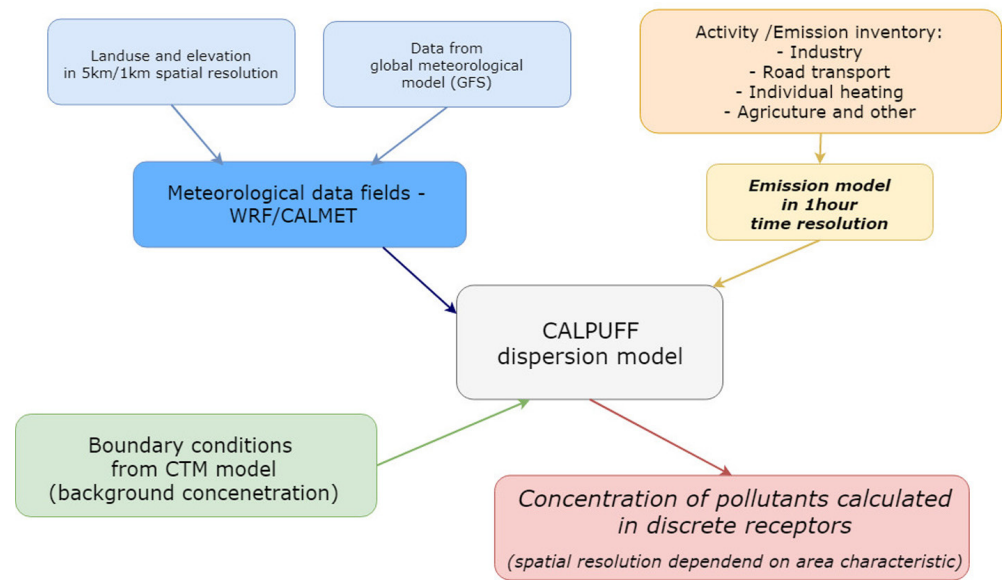

Figure. 1. Visual representation of the modelling system used in annual assessment of air quality in Lower Silesian Voivodeship.

caused by short-term exposure to $\mathrm{PM}_{2.5}$ particulate matter for cardiovascular diseases (RR 95\% $\mathrm{CI}=1.0091$ for $\left.10 \mu \mathrm{g} / \mathrm{m}^{3} \mathrm{PM}_{2.5}\right)$ and respiratory diseases (RR 95\% CI = 1.0190 for $10 \mu \mathrm{g} / \mathrm{m}^{3} \mathrm{PM}_{2.5}$ ) diseases [WHO, $2013 \mathrm{~b}$ ].

It was assumed that the daily value of $\mathrm{PM}_{2.5}$ particulate matter concentration, for which the health effects are negligible, equals $3.3 \mu \mathrm{g} / \mathrm{m}^{3}$.
This value was calculated on the grounds of average daily values in 2017 as a result of mathematical modelling outside the heating season, from May until September, occurring in the created zones A, B and C for all the Lower Silesian resorts.

The assessment of exposed patients was performed taking into account the estimated number of people based on the number of night's

Table 2. Summary of basic information about health resorts including indicators important for the impact of air pollution on health

\begin{tabular}{|c|c|c|c|c|c|c|c|c|}
\hline \multirow[b]{2}{*}{ Ordinal } & \multicolumn{3}{|c|}{ Resort } & \multicolumn{4}{|c|}{ Resort population } & \multirow[b]{2}{*}{ Curing profiles } \\
\hline & Name & $\begin{array}{l}\text { Number of } \\
\text { therapeu- } \\
\text { tical units }\end{array}$ & $\begin{array}{l}\text { Night's } \\
\text { lodgings }\end{array}$ & $\begin{array}{c}\text { A } \\
\text { Zone }\end{array}$ & $\begin{array}{c}\text { B } \\
\text { Zone }\end{array}$ & $\begin{array}{c}\text { C } \\
\text { Zone }\end{array}$ & & \\
\hline 1 & Długopole-Zdrój & 7 & 110 & 217 & 385 & 358 & $5,0 \%$ & (6), (7), (11), (12), (15), (16) \\
\hline 2 & Duszniki-Zdrój & 8 & 445 & 1395 & 1595 & 1639 & $97,9 \%$ & $\begin{array}{l}\text { (1), (2), (3), (5), (7), (11), (12), } \\
(14),(15),(16),(17),(18)\end{array}$ \\
\hline 3 & Jedlina-Zdrój & 4 & 114 & 283 & 1174 & 3395 & $99,3 \%$ & $\begin{array}{l}\text { (1), (2), (3), (8), (11), (12), } \\
(15)\end{array}$ \\
\hline 4 & $\begin{array}{l}\text { Cieplice Śląskie- } \\
\text { Zdrój }\end{array}$ & 12 & 703 & 757 & 2899 & 5366 & $11,3 \%$ & (8), (10), (11), (12), (14), (17) \\
\hline 5 & Kudowa-Zdrój & 8 & 835 & 805 & 3687 & 5462 & $99,4 \%$ & $\begin{array}{l}\text { (3), (4), (6), (7), (11), (12), } \\
(15),(18)\end{array}$ \\
\hline 6 & Lądek-Zdrój & 15 & 403 & 1788 & 3086 & 1747 & $79,1 \%$ & $\begin{array}{l}\text { (5), (7), (11), (12), (13), (14), } \\
\text { (17) }\end{array}$ \\
\hline 8 & Przerzeczyn-Zdrój & 6 & - & 95 & 196 & 3634 & $70,8 \%$ & (9), (11), (12) \\
\hline 7 & Polanica-Zdrój & 8 & 749 & 1587 & 3500 & 1270 & $99,6 \%$ & (2), (3), (11), (12), (15) \\
\hline 9 & Szczawno-Zdrój & 14 & 574 & 1250 & 3079 & 1279 & $99,3 \%$ & $\begin{array}{l}\text { (1), (2), (8), (11), (12), (15), } \\
(16),(17),(18)\end{array}$ \\
\hline 10 & Czerniawa-Zdrój & 3 & 621 & 75 & 0 & 0 & $1,7 \%$ & $\begin{array}{l}\text { (1), (2), (3), (11), (12), (16), } \\
\text { (17) }\end{array}$ \\
\hline 11 & Świeradów-Zdrój & 9 & 621 & 1285 & 2519 & 337 & $98,3 \%$ & $\begin{array}{l}\text { (1), (2), (3), (5), (7), (11), (12), } \\
(13),(14),(16),(17)\end{array}$ \\
\hline & Altogether & 94 & 5175 & 537 & 2120 & 4486 & & \\
\hline
\end{tabular}

* Resort curing profiles: (1) lower respiratory tract diseases, (2) upper respiratory tract diseases, (3) cardiovascular and high blood pressure diseases, (4), endocrinologic dieseases, (5) female diseases, (6) blood and hemoplastic diseases, (7) peripheral blood vessel diseases, (8) kidney and urinary tract diseases, (9) neurological diseases, (10) eye and eye adnexa diseases, (11) orthopedic trauma diseases, (12) rheumatological diseases, (13) skin diseases, (14) nervous diseases, (15) gastrointestinal system diseases, (16) diabetes, (17) osteoporosis, (18) obesity 
lodgings in resort protection facilities, taken from Polish Central Statistical Office (CSO) statistics [https://stat.gov.pl]. The duration of resort treatment was included in the risk evaluation. The stay of an adult in a hospital or a sanatorium lasts 21 days, in the case of rehabilitation it amounts to 28 days, whereas the outpatient treatment of children and adults takes from 6 to 18 days. For the analyses, the length of one batch was assumed to be 21 days with one additional day for the preparation for the next batch. Thus, the year was divided into 1622-day batches most often from January 3rd to December 26th.

\section{RESEARCH RESULTS AND DISCUSSION}

\section{Characteristic of air quality in some resorts based on the PM10 particulate matter measurement results}

The variability of mean annual $\mathrm{PM}_{10}$ concentration from 2012 to 2018 is presented in figure 2. The conducted data analysis lets us conclude that the limit value level of mean annual $\mathrm{PM}_{10}$ concentration has not been exceeded in any of the stations. At all the analysed points, the WHO-recommended value $\left(20 \mu \mathrm{g} / \mathrm{m}^{3}\right)$ of this parameter has been exceeded. In the case of the Szczawno-Zdrój resort, a decrease in the particulate matter concentration between 2012 and 2016 (from $39.6 \mu \mathrm{g} / \mathrm{m}^{3}$ to $27.7 \mu \mathrm{g} / \mathrm{m}^{3}$ ) and a minuscule raise in the following years (up to the value of $29.4 \mu \mathrm{g} / \mathrm{m}^{3}$ in 2018) were ascertained. Apart from the situation in 2012 and 2013 in the SzczawnoZdrój resort (where the value of this parameter was $39.6 \mu \mathrm{g} / \mathrm{m}^{3}$ and $34.2 \mu \mathrm{g} / \mathrm{m}^{3}$, respectively), the average annual concentrations in other resorts included in analyses were lower (ranging from $22.8 \mu \mathrm{g} / \mathrm{m}^{3}$ to $34 \mu \mathrm{g} / \mathrm{m}^{3}$ ) than the value of the contrywide-calculated $W S a$ presently available for Poland for years 2012-2017 and changing from $36 \mu \mathrm{g} / \mathrm{m}^{3}$ to $31.7 \mu \mathrm{g} / \mathrm{m}^{3}$.

In 2017, the concentration of $\mathrm{PM}_{10}$ was measured in 4 health resorts in Lower Silesia (Fig. 2). The analyses conducted showed that the mean values were much higher (from $51 \%$ to $74 \%$ ) than in the seaside resort of Sopot $\left(\mathrm{Sa}=16.8 \mu \mathrm{g} / \mathrm{m}^{3}\right)$, where the WHO-recommended concentration level was kept until 2017, and slightly lower than in Busko-Zdrój (from 5\% to 17\%).

In turn, the Smax36 values (fig. 3), exceeded the limit value level in the analysed locations in the studied period (fig. 3); however, a decline in the value of the parameter is discernible in Szczawno-Zdrój (from $86 \mu \mathrm{g} / \mathrm{m}^{3} \mathrm{t} 51.5 \mu \mathrm{g} / \mathrm{m}^{3}$ ) and a relatively stable situation is observed in Cieplice Śląskie-Zdrój (values ranging from $52.4 \mu \mathrm{g} / \mathrm{m}^{3}$ in 2014 to $49.2 \mu \mathrm{g} / \mathrm{m}^{3}$ in 2018). In this case, especially between 2015 and 2017, one can observe a significantly lower value of the indicator in the Lower Silesian resorts than the value of WSTax 36 (ranging from $67.6 \mu \mathrm{g} / \mathrm{m}^{3}$ in 2012 to $58.6 \mu \mathrm{g} / \mathrm{m}^{3}$ in 2017) for the whole country. In 2017, the Smax 36 indicator slightly exceeded the normative value in Cieplice-Zdrój $\left(52.9 \mu \mathrm{g} / \mathrm{m}^{3}\right)$ and Szczawno-Zdrój $\left(51.8 \mu \mathrm{g} / \mathrm{m}^{3}\right)$, whereas in 2018 such a situation only took place in Szczawno-Zdrój $\left(51.5 \mu \mathrm{g} / \mathrm{m}^{3}\right)$. In 2017 and 2018, the concentrations in BuskoZdrój were higher than the ones recorded in Lower Silesian health resorts (the WSmax36 values higher by 5\%-31\%). In Cieplice Śląskie-Zdrój, Kudowa and Szczawno-Zdrój, the concentrations were higher than in Sopot (the WSmax36 value higher by 25\%-98\%), and in Lądek-Zdrój the values were comparable (a difference of around 1\%).

The analysis of measurement results showed that in all the localisations studied, the seasonal variance of particulate matter concentration is very visible, both in 2017 and 2018 (fig. 4 a-b).

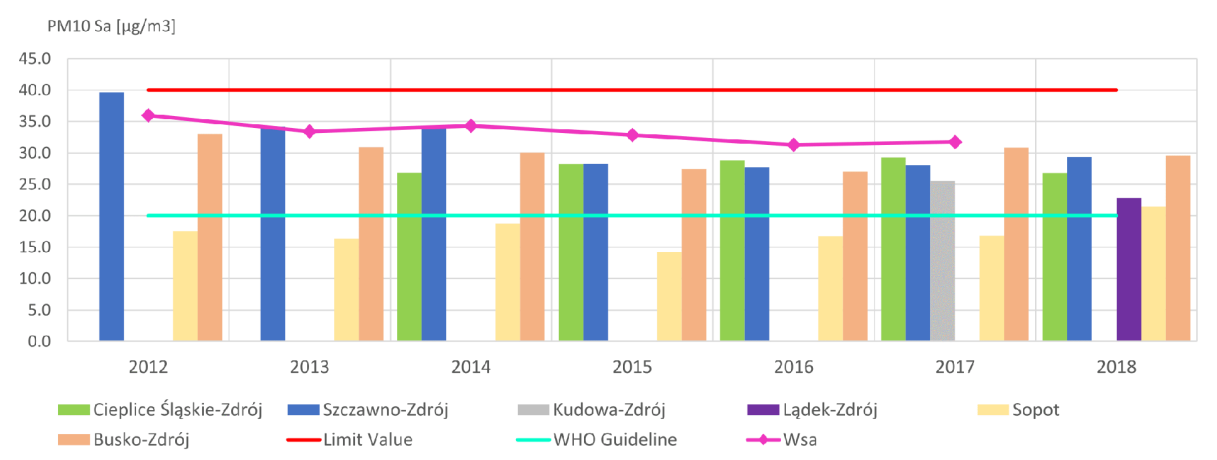

Figure. 2. Changes in mean annual PM10 concentrations values in 2012-2018 (Source: own elaboration based on SEM data) 


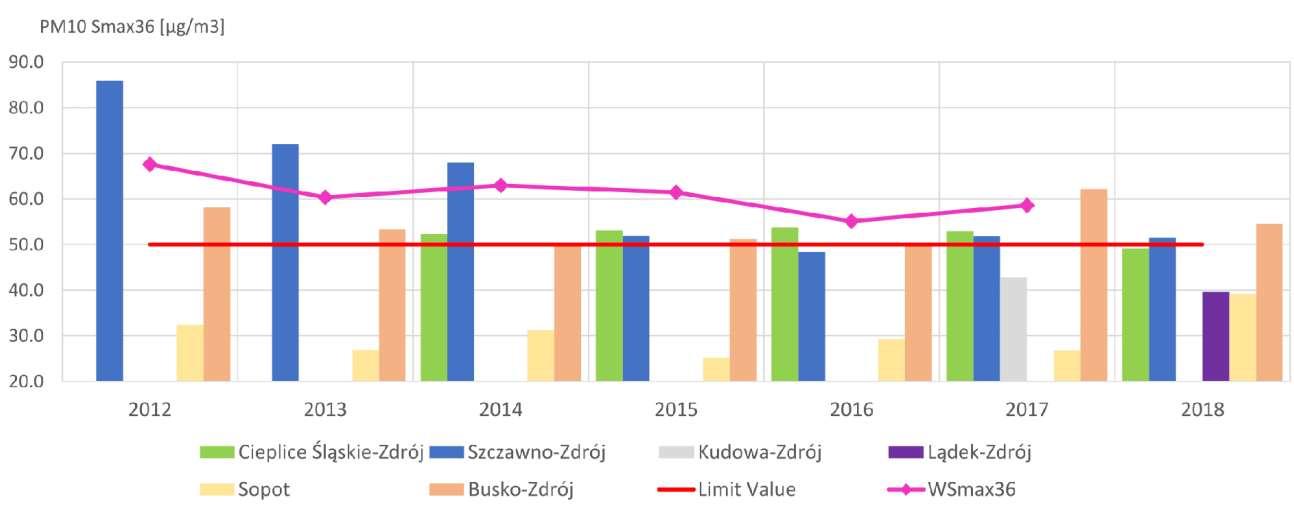

Figure. 3. Changes in values of 36th maximal 24-hour concentration of $\mathrm{PM}_{10}$ in 2012-2018 (Source: own elaboration based on SEM data).

The highest mean concentrations were recorded in the winter of 2017 in Cieplice Śląskie-Zdrój (from $11 \mu \mathrm{g} / \mathrm{m}^{3}$ to $82 \mu \mathrm{g} / \mathrm{m}^{3}$ ), where also the most cases of exceeding the daily concentration limit value have occurred (the parameter $P M_{10} L>50$, values from 0 to 17 in January). 2018 was characterised by the lowest monthly concentrations (from $17 \mu \mathrm{g} / \mathrm{m}^{3}$ to $60 \mu \mathrm{g} / \mathrm{m}^{3}$ ), as well as the highest number of exceedances in Szczawno-Zdrój (from 0 to 15 days in February).

In the first two months of 2017, in Lower Silesian health resorts, high and very high concentrations of $\mathrm{PM}_{10}$ were recorded during the smog episodes encompassing most of the country (maximal daily mean concentrations in this period were: $176 \mu \mathrm{g} / \mathrm{m}^{3}$ in Kudowa-Zdrój,
$230 \mu \mathrm{g} / \mathrm{m}^{3}$ in Cieplice Śląskie-Zdrój and 231 $\mu \mathrm{g} / \mathrm{m}^{3}$ in Szczawno-Zdrój). In Cieplice ŚląskieZdrój, the cases of daily concentrations exceeding $100 \mu \mathrm{g} / \mathrm{m}^{3}$ numbered 18 in 2017 (mainly in January and February), whereas in Kudowa and Szczawno there were 12 in each. There have also been singular cases of exceeding the Polish social information level, which is the mean 24-hour concentration of at least 200 $\mu \mathrm{g} / \mathrm{m}^{3}$ : in Cieplice Śląskie-Zdrój two days in January $\left(205 \mu \mathrm{g} / \mathrm{m}^{3}\right.$ and $\left.230 \mu \mathrm{g} / \mathrm{m}^{3}\right)$ as well as three days at the beginning of February (from $207 \mu \mathrm{g} / \mathrm{m}^{3}$ to $228 \mu \mathrm{g} / \mathrm{m}^{3}$ ), as well as on February 13 and 14 in Szczawno-Zdrój (respective values: $231 \mu \mathrm{g} / \mathrm{m}^{3}$ and $209 \mu \mathrm{g} / \mathrm{m}^{3}$ ). For this reason, further analyses were conducted for 2017. a)

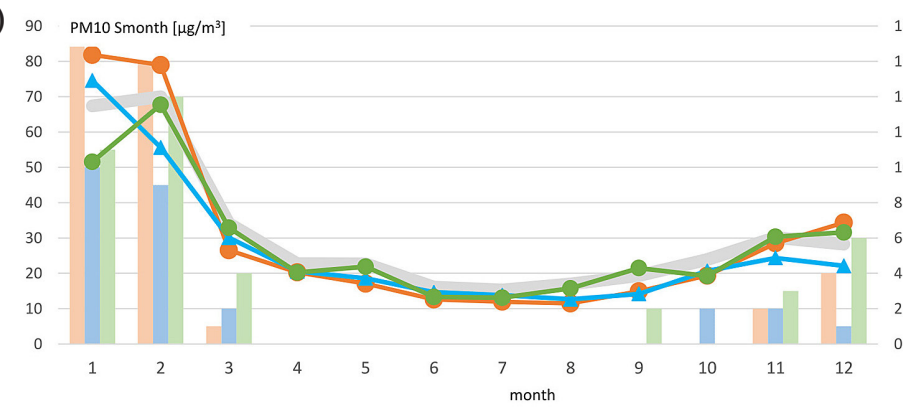

b)

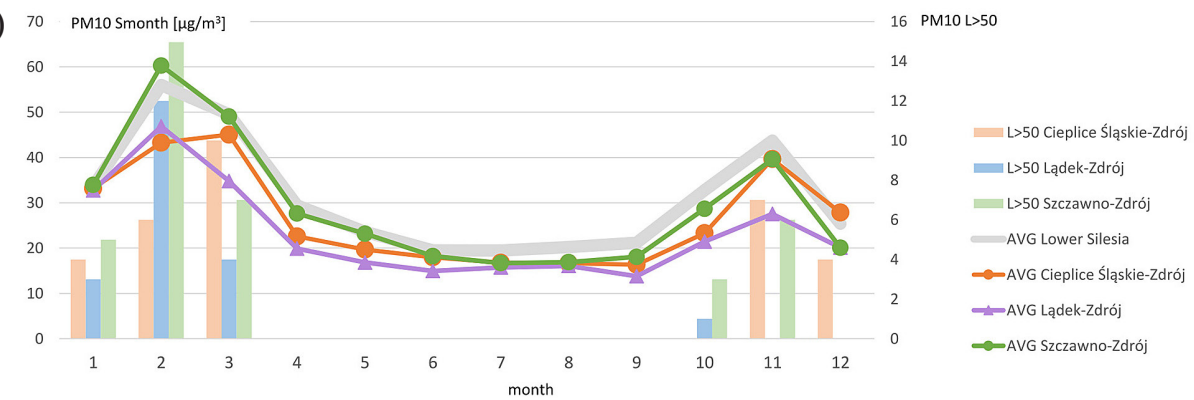

Figure. 4. Variance in mean monthly $\mathrm{PM}_{10}$ concentration and in the number of days with concentration exceeding $50 \mu \mathrm{g} / \mathrm{m}^{3}$ in consecutive months of 2017 (a) and 2018 (b). (Source: own elaboration based on SEM data) 


\section{Analysis of the results from mathematical modelling}

The exemplary results of maximum $\mathrm{PM}_{10}$ concentrations in Lower Silesian health resorts, obtained as a part of the annual air quality assessment in 2017 with use of modelling, are presented in fig. 5. The analyses indicate that the worst air quality relative to the daily $\mathrm{PM}_{10}$ concentrations in 2017 characterised the Cieplice ŚląskieZdrój resort (fig. 5a). The highest concentrations $\left(108.6 \mu \mathrm{g} / \mathrm{m}^{3}\right)$ occurred in resort zone $\mathrm{C}$ and were twice above the permitted level. The permissible $\mathrm{PM}_{10}$ levels were also exceeded in Kudowa-Zdrój (in all zones), Polanica-Zdrój (resort zone $\mathrm{C}$ ) and in Szczawno-Zdrój (resort zone B), but the concentrations obtained via modelling were much lower and peaked at $60.8 \mu \mathrm{g} / \mathrm{m}^{3}$ in resort zone A in Kudowa-Zdrój. The best air quality characterizes Świeradów-Zdrój, Czerniawa-Zdrój and Przerzeczyn-Zdrój.

On the basis of the results of modelling, in the case of mean annual $\mathrm{PM}_{10}$ concentrations, the permissible level was exceeded only in the $\mathrm{C}$ resort zone in Cieplice-Śląskie Zdrój (figure 5b). In other resorts, the problem of exceeding the limit value level with regard to mean annual $\mathrm{PM}_{10}$ concentration is practically non-existent. In the case of $\mathrm{PM}_{2.5}$ particulate matter, the analyses of modelling (figure 6) also showed that the $\mathrm{PM}_{2.5}$ mean annual permissible level was only exceeded in Cieplice Śląskie-Zdrój with highest concentrations in resort zone $\mathrm{C}\left(32 \mu \mathrm{g} / \mathrm{m}^{3}\right)$. In other resorts, the concentration stayed even under $20 \mu \mathrm{g} / \mathrm{m}^{3}$ (permissible level since 2020).

The cause of poor air quality in Cieplice Śląskie-Zdrój, according to the analysis of the results of calculation presented in figures 5 and 6 , may be the home boiler houses using hard coal as fuel.

Therefore, the analysis of maximal particulate matter pollution concentration showed that the problem of infracting quality standards both in mean daily and mean annual concentration occurs in Cieplice Śląskie-Zdrój. Hence, regional analyses have been carried out in a spatial way. For the assumed calculation scenario for mean daily $\mathrm{PM}_{10}$ concentrations, the range of exceedance encompassed practically the whole resort zones A and B and a sizeable portion of resort zone $\mathrm{C}$, altogether an area of approximately 830 ha. A smaller aerial range of exceedances was observed for the calculation scenario which included daily $\mathrm{PM}_{10}$ and $\mathrm{PM}_{2.5}$

a)

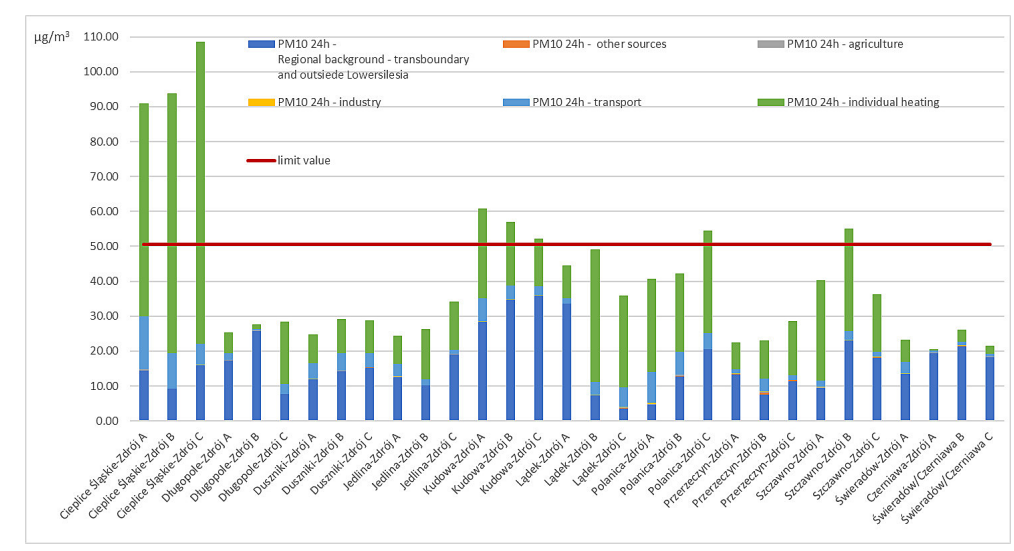

b)

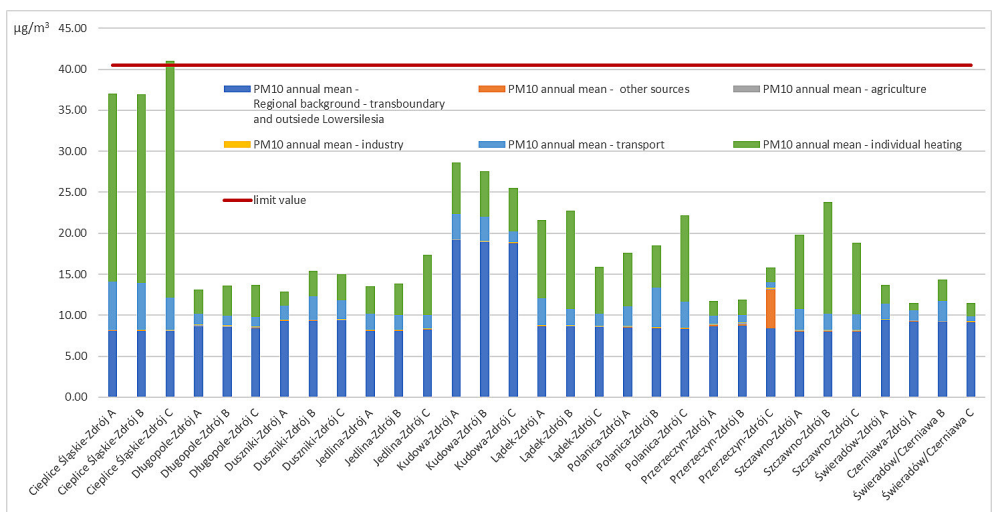

Figure 5. Maximal mean daily(a) and mean annual(b) $\mathrm{PM}_{10}$ concentrations, including the influence of individual emission types in Lower Silesian resort zones in 2017 derived from modelling. 


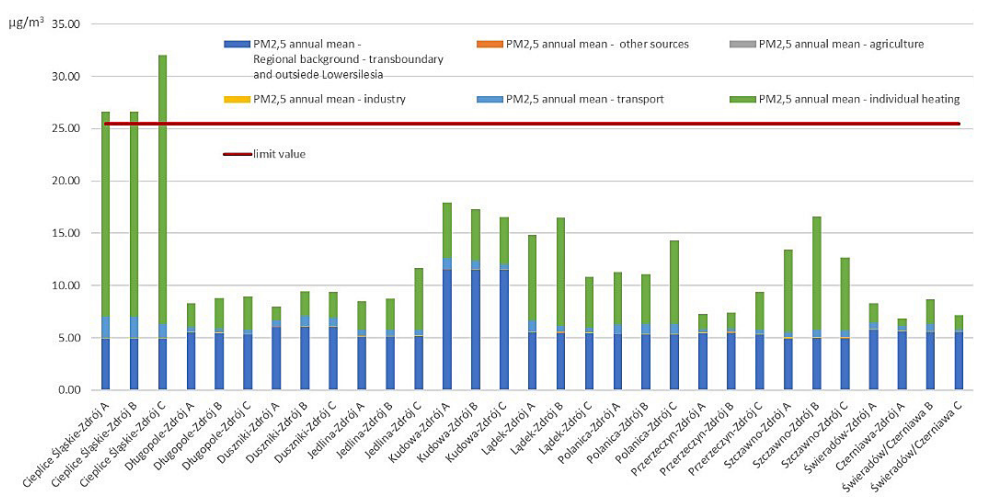

Figure 6. Maximal annual concentration of $\mathrm{PM}_{2.5}$ including the influence of individual emission types in Lower Silesian resort zones in 2017 derived from modelling.

concentrations, see figures $7 \mathrm{~b}$ and $7 \mathrm{c}$. For comparison, in the resorts where mean daily concentrations could be considered elevated (with respect to other analysed resorts), i.e. in Kudowa-Zdrój and Szczawno-Zdrój, the areas of exceedance were obtained for zones A and B (figure 8a) and zone B (figure 8b), respectively. In Kudowa-Zdrój, the area with permissible mean daily $\mathrm{PM}_{10}$ level amounted to $87.5 \mathrm{ha}$, and the magnitude of these areas in Szczawno-Zdrój was no higher than 6 ha. a)

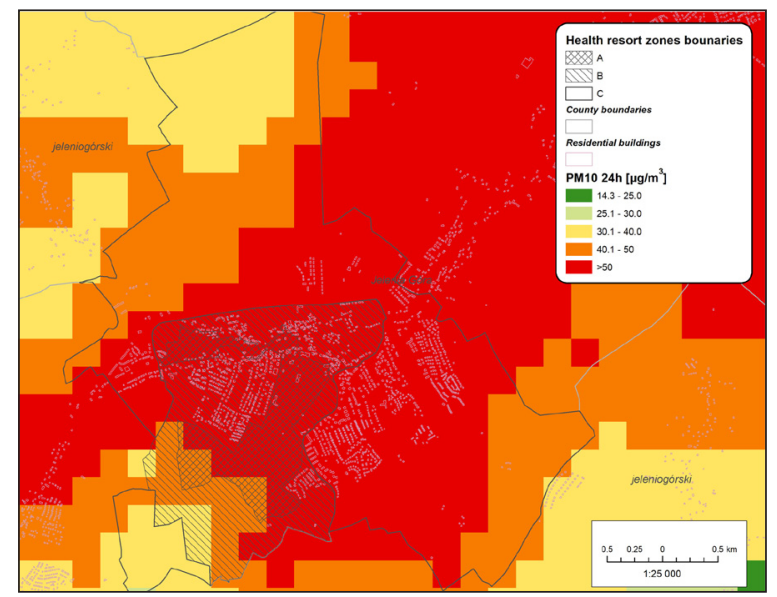

b)

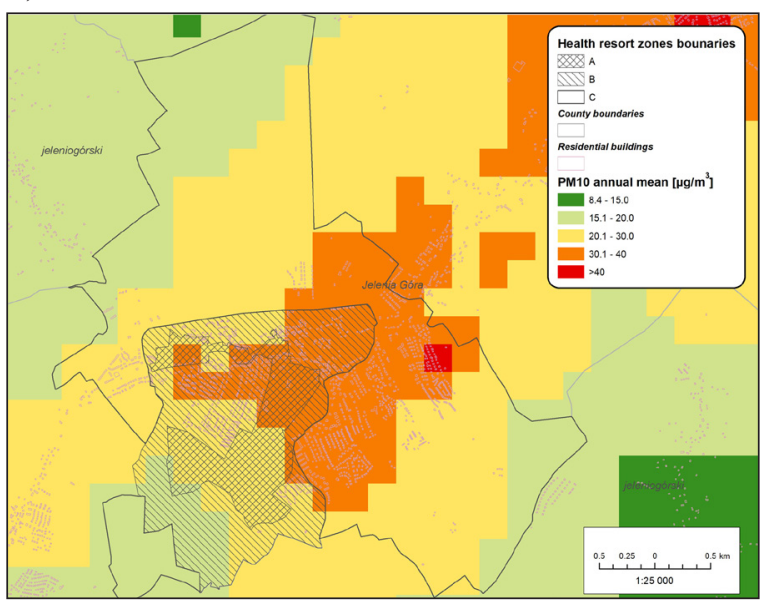

c)

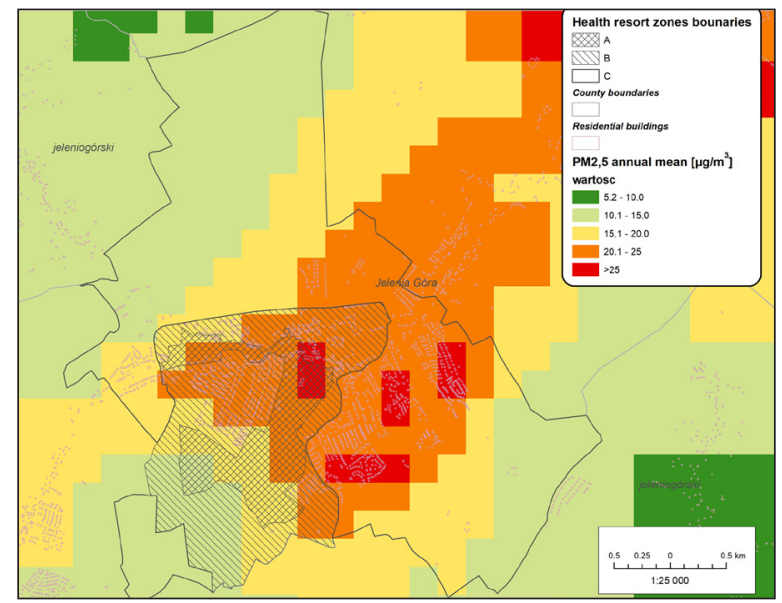

Figure 7. The area where the $24 \mathrm{~h}$ permissible level of $\mathrm{PM}_{10}$ was exceeded in Cieplice Śląskie-Zdrój, obtained on the basis mean daily $\mathrm{PM}_{10}$ (a), mean annual $\mathrm{PM}_{10}$ (b) and $\mathrm{PM}_{2,5}$ (c) concentrations values as a result of modelling for 2017 
a)

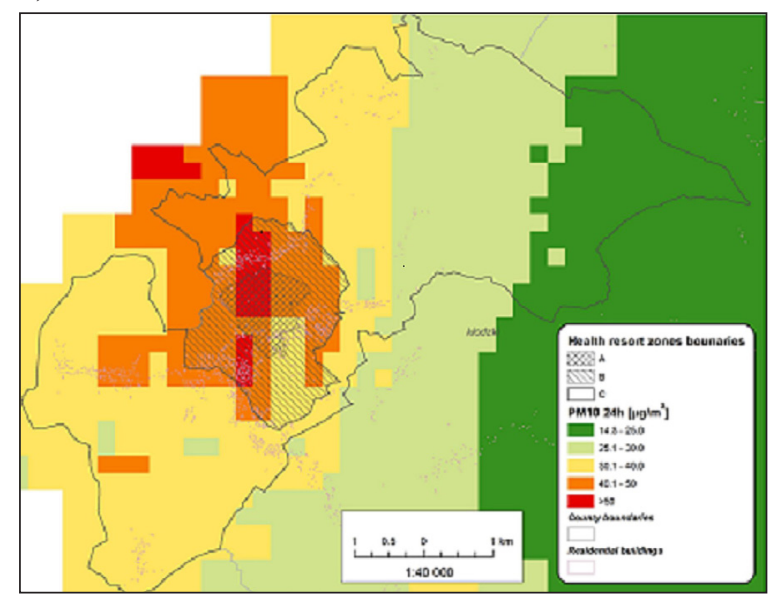

b)

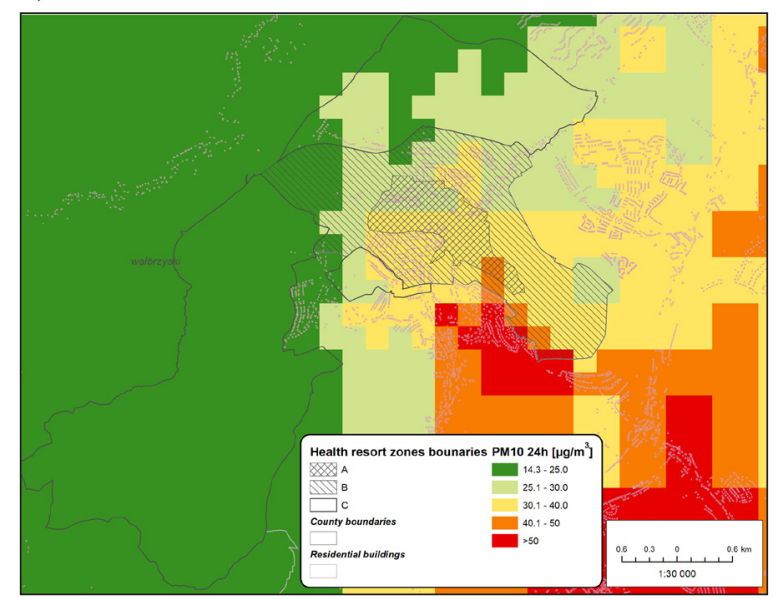

Figure 8. Area with the $24 \mathrm{~h} \mathrm{PM}_{10}$ permissible level exceeded in Kudowa-Zdrój (a) and Szczawno-Zdrój (b) obtained on the basis of results of modelling for 2017.

\section{Health risk assessment}

The obtained results concerning mean annual health risk connected with short-term (24-hour) exposure to air contamination with $\mathrm{PM}_{2.5}$ for Lower Silesian health resorts show that in 2017 , the highest values (much higher than for other resorts) occurred in Cieplice Śląskie-Zdrój and Kudowa-Zdrój. In these resorts, there are many places dedicated to patients, i.e. the people staying in a resort establishment for inpatient treatment or utilising health benefits in outpatient treatment mode (Table 2). In the case of Kudowa-Zdrój it is especially important, because this resort conducts treatment of cardiovascular diseases, and the average risk indicator for such diseases equalling $0.7 \%$ is twice higher than in other resorts analysed in this regard (Table 3 ). It should be noted that the differences between risk levels in Lower Silesian resorts are insignificant.
The levels of relative health risk related to the air pollution with $\mathrm{PM}_{2.5}$ are not evenly distributed in time. The highest levels occur in the heating season, especially in smog situations. In 2017, highest average risk levels were recorded for four 21-day stays at the turn of January and February (stays no. 1 and 2) and November and December (stays no. 15 and 16). A characteristic trait of 2017 is a considerable decrease in the $\mathrm{PM}_{25}$ concentration during the 3 rd stay, which caused a significant drop in risk, which in turn rose in the second half of March (4th stay) - see Fig. 9.

Taking into account the number of night's lodgings in health resorts, as it is officially stated by CSO and presented in Table 2, a heightened risk of exacerbation of cardiovascular and respiratory diseases resulting in the need for hospitalization, in the analysed Lower Silesian health resorts during 4 stays: 1, 2, 15 and 16 could concern as many as 20 thousand people,

Table 3. Average annual health risk for cardiovascular and respiratory diseases related to short-term exposure to air pollution with $\mathrm{PM}_{2.5}$ in Lower Silesian health resorts in 2017

\begin{tabular}{|c|c|c|}
\hline \multirow{2}{*}{ Health resort } & \multicolumn{2}{|c|}{ Mean annual value of the risk of hospitalization for $\mathrm{PM}_{2,5}$ particulate matter $(95 \% \mathrm{CL})$} \\
\hline & Cardiovascular diseases & Respiratory diseases \\
\hline Cieplice Śląskie-Zdrój & $1,3(-3,0 ; 5,6)$ & $2,7(-6,3 ; 11,7)$ \\
\hline Czerniawa-Zdrój & $0,2(-0,7 ; 1,2)$ & $0,5(-1,5 ; 2,5)$ \\
\hline Długopole-Zdrój & $0,3(-0,8 ; 1,3)$ & $0,6(-1,7 ; 2,8)$ \\
\hline Duszniki-Zdrój & $0,3(-0,7 ; 1,3)$ & $0,6(-1,5 ; 2,7)$ \\
\hline Jedlina-Zdrój & $0,4(-0,9 ; 1,6)$ & $0,7(-1,9 ; 3,4)$ \\
\hline Kudowa-Zdrój & $0,7(-1,2 ; 2,6)$ & $1,5(-2,5 ; 5,5)$ \\
\hline Lądek-Zdrój & $0,3(-0,9 ; 1,6)$ & $0,7(-1,9 ; 3,3)$ \\
\hline Polanica-Zdrój & $0,4(-1,0 ; 1,7)$ & $0,7(-2,0 ; 3,5)$ \\
\hline Przerzeczyn-Zdrój & $0,3(-0,9 ; 1,5)$ & $0,7(-1,9 ; 3,2)$ \\
\hline Szczawno-Zdrój & $0,5(-1,4 ; 2,4)$ & $1,0(-3,0 ; 4,9)$ \\
\hline Świeradów-Zdrój & $0,2(-0,7 ; 1,2)$ & $0,5(-1,5 ; 2,5)$ \\
\hline
\end{tabular}


a)

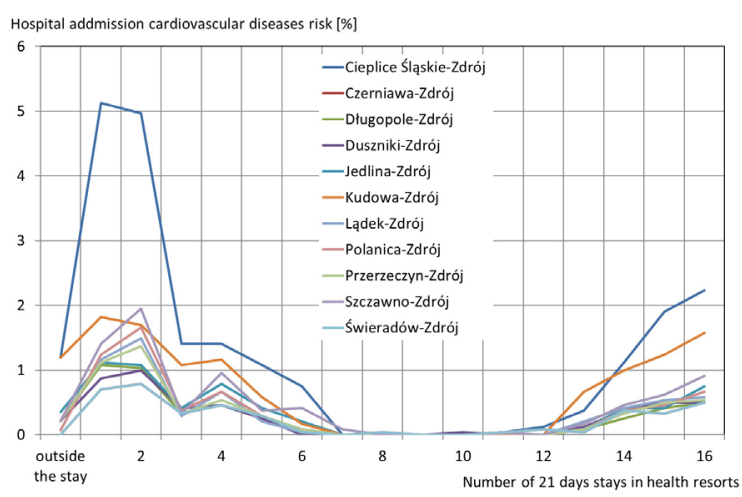

b)

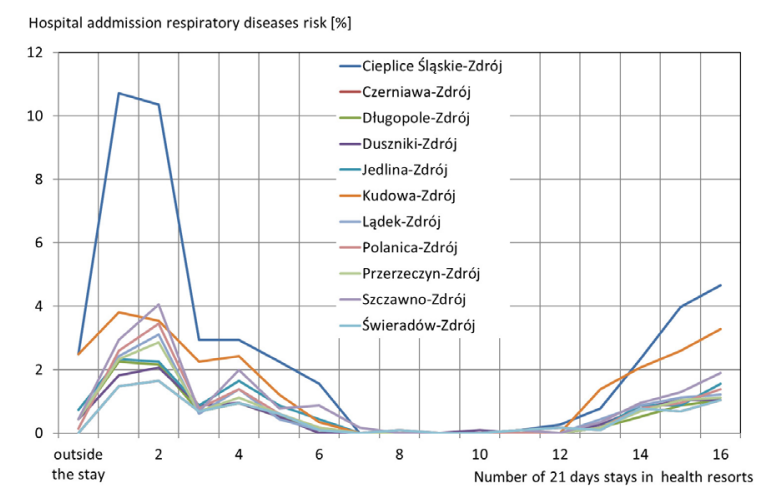

Figure 9. Increases of hospital admissions risk for cardiovascular (a) and respiratory (b) diseases during stays with exposure to $\mathrm{PM}_{2.5}$ concentrations in Lower Silesian health resorts in 2017.

with 97 thousand being cured during the whole year [https://stat.gov.pl]. Because of the lack of information about the number of people being cured from these diseases and the people staying during said stays or people located in private quarters, the scale of the threat may be much larger.

As it was mentioned before, the highest concentrations among the analysed resorts were observed in Cieplice Śląskie-Zdrój. It should be noted that from the patients' viewpoint, this resort does not conduct treatment of respiratory or cardiovascular diseases (lack of most sensitive patients exposed). Because the short-term air pollution exposure causes mostly respiratory diseases, the health risk assessment for this resort was carried out for the risk of hospitalisation from such diseases. The partition of the resort into zones $\mathrm{A}, \mathrm{B}$ and $\mathrm{C}$ was included in the analyses.
The obtained results of health risk assessment for Cieplice Śląskie-Zdrój (Fig. 10) show that despite exceedances in the normative values of $\mathrm{PM}_{10}$ in the $\mathrm{C}$ zone in 2017, the average level of the risk of hospitalisation due to respiratory diseases was over twice higher in zone A than in zone $\mathrm{C}$. The greatest differences occurred in stays 1 and 12 . It is worth noticing that in zones A and B in the heating season, the analysed risk levels are much higher than the average level for the whole resort.

It should be noted that despite much higher $\mathrm{PM}_{2.5}$ particulate matter concentrations and thus the calculated hospital admissions risk indicators for Cieplice Śląskie-Zdrój in relation to other Lower Silesian health resorts, the potential health effects connected with air pollution in this resort may be much lower than in other resorts because of the lack of patients suffering from cardiovascular or respiratory diseases (groups most sensitive to air pollution).

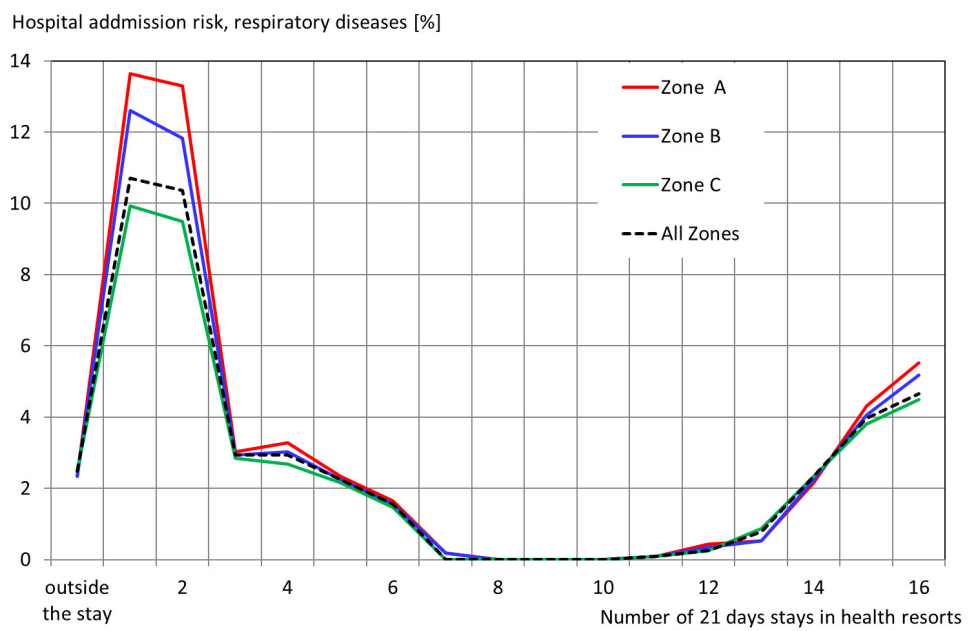

Figure 10. Increase in risk of hospitalisation due to respiratory diseases during batches with short-term exposure to the concentrations of $\mathrm{PM}_{2.5}$ in zones A, B and C of the Cieplice Śląskie-Zdrój resort in 2017. 


\section{CONCLUSIONS}

The conducted air quality analyses involving both a comparative analysis of the variability of particulate matter concentrations with inclusion of indicators obtained on the basis of measurement and the values obtained through modelling, showed that the so-called low-stack emission and meteorological conditions, which affect i.a. the diminution of the possibility of venting health resorts situated in mountain basins, and thus also negatively affect the quality of air and the possibility of depletion of remedying properties in Lower Silesian health resorts has an important impact on the elevated concentrations values.

The results obtained in calculations in respect of the health risk assessment show that in the present situations, the batches for patients requiring intense therapy for cardiovascular diseases and above all respiratory diseases should be planned between batches 5 and 12, i.e. from the beginning of April until mid-September. Without taking effective actions, not only in resorts, but also outside, one should bear in mind that the expected improvement of health in the chronically ill may not occur. Therefore, having established a legal basis for air protection, the next key steps in resort areas should be building appropriate attitudes in citizens and resort companies, explaining their responsibility for the state of atmospheric air and guaranteeing the financial support mechanisms enabling the introduction of new technologies in heating systems that will increase the energy efficiency of buildings, devices, installations and whole resort towns.

\section{REFERENCES}

1. Chief Inspector for Environmental Protection (CIEP). 2015. The State Environmental Monitoring Program for 2016-2020, Warsaw.

2. https://irt.wroc.pl/pliki/ekspertyza_wskazujaca efektekologiczny_w_dolnoslaskich_uzdrowiskach/ index.html (access: 07.08.2019) (in Polish). Expert opinion indicating the ecological effect of introducing restrictions and bans on the operation of solid fuel combustion installations in the areas of the " $A$ ", "B" and "C" spa protection zones in the Lower Silesian Voivodship.

3. https://powietrze.gios.gov.pl/pjp/archives (access: 3.08.2019) (in Polish).

4. https://stat.gov.pl (access: 3.08.2019).
5. Iwanek J., Mitosek G., Kobus D. 2018. (CIEP), Air quality in Poland in 2017 in the light of the results of measurements carried out as part of the State Environmental Monitoring", work commissioned by the Chief Inspectorate of Environmental Protection by the Institute of Environmental Protection - National Research Institute, Warsaw.

6. Journal of Laws of 2018, item 799, as amended. Environmental Protection Act of 27 April 2001, (Announcement of the Marshal of the Parliament of the Republic of Poland of 13 April 2018 regarding the publication of a uniform text of the Act - Polish Environmental Protection Law.

7. Journal of Laws 2018, item 1119. Regulation of the Polish Minister of the Environment of June 8, 2018 regarding the assessment of levels of substances in the air.

8. Journal of Laws of 2012, item 1031. Regulation of the Polish Minister of the Environment of August 24, 2012 regarding levels of some substances in the air.

9. Katsouyanni K. 2003. Ambient air pollution and health. British Medical Bulletin, 68: 143-156

10. Lim SS, et al. 2013. A comparative risk assessment of burden of disease and injury attributable to 67 risk factors and risk factor clusters in 21 regions, 19902010: a systematic analysis for the Global Burden of Disease Study 2010. Lancet, 380: 2224-2260.

11. Official Journal of the Lower Silesia, Wrocław, February 25, 2014, item 985, Resolution No. XLVI / 1544/14 of the Parliament of the Lower Silesia Voivodship of February 12, 2014 regarding the adoption of an Air Protection Program for the Lower Silesia Voivodship.

12. Official Journal of the Lower Silesian Voivodeship, Wrocław, November 2 2017, item 4475 Resolution No. XL /1330/17 of the Parliament of the Lower Silesian Voivodeship of October 26, 2017 regarding the adoption of an Air Protection Program for the Lower Silesian Zone due to exceeding the permissible level of PM2.5 suspended in the air.

13. Official Journal of the Dolnośląskie Voivodship, Wrocław, December 8. 2017, item 5154, Resolution No. XLI /1406/17 of the Parliament of the Lower Silesia Voivodship of November 30, 2017 regarding introduction of restrictions and bans in the area of health resorts in the Lower Silesia Voivodship in the field of fuel combustion installations.

14. Official Journal of the EU L. 152 of 11.06.2008, Directive 2008/50/EC of the European Parliament and of the Council of 21 May 2008 on air quality and cleaner air for Europe, (p. 1).

15. Official Journal EU L 23 of 26.01.2005. Directive 2004/107 / EC of the European Parliament and of the Council of 15 December 2004 on arsenic, cadmium, mercury, nickel and polycyclic aromatic hydrocarbons in ambient air, (p. 3). 
16. Pietrzyk-Sokulska E., Smol M., Lelek Ł., Cholewa M. 2016. Low-emission economy plan as an element of sustainable development of communes No. 92, 225-242.

17. Polish Journal of Laws. 2005 No. 167 item 1399 with later changes. Act of 28 July 2005 on spa treatment, spas and spa protection areas and spa boroughs.

18. Samet J, Krewski D. 2007. Health effects associated with exposure to ambient air pollution. Journal of Toxicology and Environmental Health, Part A 70, 227-242.

19. Team for developing the concept of changes in the field of spa treatment system. 2017. The final report of the Team (Team appointed by the ordinance of the Polish Minister of Health of November 22, 2016), Warsaw.

20. Voivodship Inspectorate for Environmental Protection in Wroclaw (VIEP Wroclaw). 2014. Assessment of the levels of substances in the air and the results of the classification of zones in the Lower Silesian Voivodship for 2013, Wrocław.
21. Voivodship Inspectorate for Environmental Protection in Wroclaw (VIEP Wroclaw). 2018. Assessment of levels of substances in the air and the results of the classification of zones of the Lower Silesian Voivodship for 2017 , Wrocław.

22. World Health Organization (WHO). 2006. Air quality guidelines for particular matter, ozone, nitrogen dioxide and sulphur dioxide. Global update 2005. Regional Office for Europe, Copenhagen.

23. World Health Organization (WHO). 2013 a. Health risks of air pollution in Europe - HRAPIE project Recommendations for concentration-response functions for cost-benefit analysis of particulate matter, ozone and nitrogen dioxide.

24. World Health Organization (WHO). 2013 b. Review of evidence on health aspects of air pollution (REVIHAAP). Technical report. Regional Office for Europe, Copenhagen.

25. World Health Organization (WHO). 2016. Ambient air pollution: a global assessment of exposure and burden of disease, Geneve. 